\title{
The Effect of Adathoda vasica Extract on the Haematology and Protein Content of Black Moor- Carassius auratus
}

\author{
Ambili T $\mathbf{T}^{1}$, Reenamole G. $\mathbf{R}^{2}$, George D'cruz, $\mathbf{F}^{3}$ \\ ${ }^{1,2,3}$ Department Of Zoology, Zoology Research Centre, Fatima Mata National College, Kollam, University of Kerala, \\ Thiruvananthapuram- 695581, India
}

\begin{abstract}
Aquaculture systems are known stressful ecosystems. The stress is buffered by the culture fish via a number of behavioral, physiological or even genetic mechanisms. Adathoda vasica is a well known drug in the Ayurvedic and Unani system of medicine. The leaves contain a small amount of an essential oil, a crystalline acid and a white crystalline alkaloid vasicine. The present study attempts to throw some light on the effect of Adathoda vasica extract on the stress metabolic axis of the ornamental fish Carassius auratus (Black moor), a member of the family Cyprinidae. Elevated levels of TEC, TLC, protein and glycogen at 48 hours and 72 hours in both TD1 and TD2 treatments indicated an improvement in its growth. The fluctuations seen in the parameters studied indicate a positive impetus to the stress metabolism axis. It is possible to conclude on a positive note that Adathoda vasica methanolic extract dose have a growth promoting effect on Carassius auratus.
\end{abstract}

Keywords: Aquaculture, Adathoda vasica, vasicine, Carassius auratus

\section{Introduction}

Aquaculture can be used as a means to boost the socioeconomic status of the people living at the bottom strata of the social order. For increasing the aquaculture outputs, farmers rely heavily on the use of antibiotics. As an alternative to antibiotics, biodegradable products assisting in elevating the immunological status of the culture fish is an active area of research (Murthy, 2000). Kerala, as we know, has a wealth of floristic heritage. Ayurveda offers a hoard of immunostimulant products for the well being of mankind. Adathoda vasica is a well known drug in the Ayurvedic and Unani system of medicine. It belongs to the family Acanthacea. It is recommended for a variety of ailments mostly those associated with the infections of upper respiratory tracts. The leaves and roots are antispasmodic and anti haemorrhagic. The leaves contain a small amount of an essential oil, a crystalline acid and a white crystalline alkaloid, vasicine. Its molecular structure is $\mathrm{C}_{11} \mathrm{H}_{12} \mathrm{~N}_{2} \mathrm{O}$ and melting point is $190-191{ }^{\circ} \mathrm{C}$. The leaves have the maximum content of vasicine, $0.2-0.4 \%$. Broncho-dialation, antihemorrhagic, insecticidal and antiseptic properties are attributed to vasicine.

Fishes have an immunological set up as delicate as that of man. Aqua culturists have started recognizing these delicate balances lately (Frederickson, et al., 1997). C. auratus is an important aquarium fish which belongs to the family Cyprinidae. It lives for 10 years and attain a maximum body length of $7 \mathrm{cms}$.. It has an omnivorous feeding habit and has a characteristic eye which projects strongly along the optic axis. The fish come under the Class Teleostomi, Sub class- Actinopterigii, Order- Cypriniformes, Family- Cyprinidae, Genus- Carassius and Species auratus.

\section{Materials and Methods}

\subsection{Study design and Sample Collection}

To assess the biological impact of the methanolic extract of A. vasica on Carassius auratus, a minimum effective concentration had to be found. Two doses of A. vasica were taken $-0.01 \mathrm{mg}$ (Test Dose 1) and $0.05 \mathrm{mg}$ (Test dose $2)$. These doses were given as intramuscular injections using standard micro syringe (Merk). Each experimental set up consisted of $15 \mathrm{fish} /$ test dose. The same fishes were again subjected to the determination of oxygen consumption, protein content, glycogen content, Total Erythrocyte Count (TEC) Total Leucocyte Count (TLC) and $\mathrm{Hb}$ at intervals of 24 hours, 48 hours and 72 hours subsequent to TD-1 and TD-2 injections.

\subsection{Collection of Blood Samples}

The blood of $C$. auratus was obtained by dorsal gill incision according to the method of Watson et al., (1989). The fish was manually retained in a horizontal position with the ventral side up. The left operculum was excised revealing the gill structures. Excess water and any other residual hemorrhaging resulting from the excision of the operculum was removed by blotting the area with a tissue paper. Using a pair of small surgical scissors, an incision was made to cut the efferent arteries at the junction of the apex of gill arches 1-3 and the buccal cavity (Watson et al., 1989). Blood samples were immediately collected directly in to heparinized capillary tubes placed at the site of the incision.

\subsection{Water Analysis}

Water samples were collected in $250 \mathrm{ml}$ BOD bottles from the fish tank just after the introduction of fish in to the tank and after 24 hours, 48 hours and 72 hours. 


\section{International Journal of Science and Research (IJSR) \\ ISSN (Online): 2319-7064 \\ Index Copernicus Value (2013): 6.14 | Impact Factor (2014): 5.611}

These were analyzed for the amount of oxygen consumption by the fish by employing Winkler's method.

\subsection{Alkaloid extraction:}

The crude extract was prepared from the Adathoda vasica leaves. The leaves were completely dried in the sun and in the current of hot air; and were subjected to powdering in a mixy. The powder taken in a conical flask was soaked in double volume of methanol and stirred. After 24 hours the extract was filtered and then transferred in to a crucible and maintained at $60^{\circ}$ in the oven till attaining crude powder.

\subsection{Protein Content}

The total protein content of muscle, liver and head kidney was determined by Folin-ciocalteu method using Bovine serum albumin as standard (Lowry, et al., 1951).

\subsection{Glycogen Content}

The total glycogen content of muscle, liver and head kidney was determined by the Anthrone method following Sifter et al., (1950)

\subsection{Total Blood Cell Count}

For determining Total Erythrocyte Count (TEC), the conventional haemocytometer method was used. Using Hendricks fish blood diluting fluid tightly coloured with methylene blue, the sample blood was diluted 200 times in RBC Thoma pipette. Counting was done using a haemocytometer at the high power of a microscope and calculated as Total Erythrocytes Counted $10^{6}$ (TEC $10^{6}$ ). Total Leucocyte Count (TLC) was determined along with TEC and calculated as Total Leucocytes Counted $10^{4}$ (TEC $\left.10^{4}\right)$. The erythrocytes were in the form of oval or rounded cells with a distinct nucleus.The leucocytes were small or large amorphous whose nucleus stained a slight blue colour. Duplicate counts were made for all samples and the average of the counts was taken in all cases.

\subsection{Haemoglobin Concentration}

The $\mathrm{Hb}$ content was determined by Sahlis acid haematin method. The blood samples were transferred to a Sahli pipette up to the $20 \mathrm{~mm}$ mark. Wiped out all the excess blood with a soft absorbant tissue and transferred the sample in to a transmission test tube containing $10 \mathrm{ml}$ of $0.1 \mathrm{~N} \mathrm{HCl}$. Rinsed the pipette several times in the acid solution and allowed it to stand for 3-5 minutes. The transmission was read in a calorimeter at $540 \mathrm{~nm}$. The value was then converted in to $\mathrm{gm} \%$.

\section{Results and Discussions}

The collected samples are shown in the Figures 1, 2 and 3. The results observed as per the experimental design mentioned in the materials and methods are documented in tables 1 and 2.The oxygen consumption of the experimental fishes recorded a slight increase in both TD1 and TD2 treatments. Haematological parameters especially the WBC counts exhibited greater fluctuations than RBC and haemoglobin contents. An overall increase in the protein and glycogen content of muscle, liver and head kidney is observed. From these three tissues, increase in head kidney protein content and muscle tissue glycogen content is appreciably high in both TD1 and TD2 treatments.

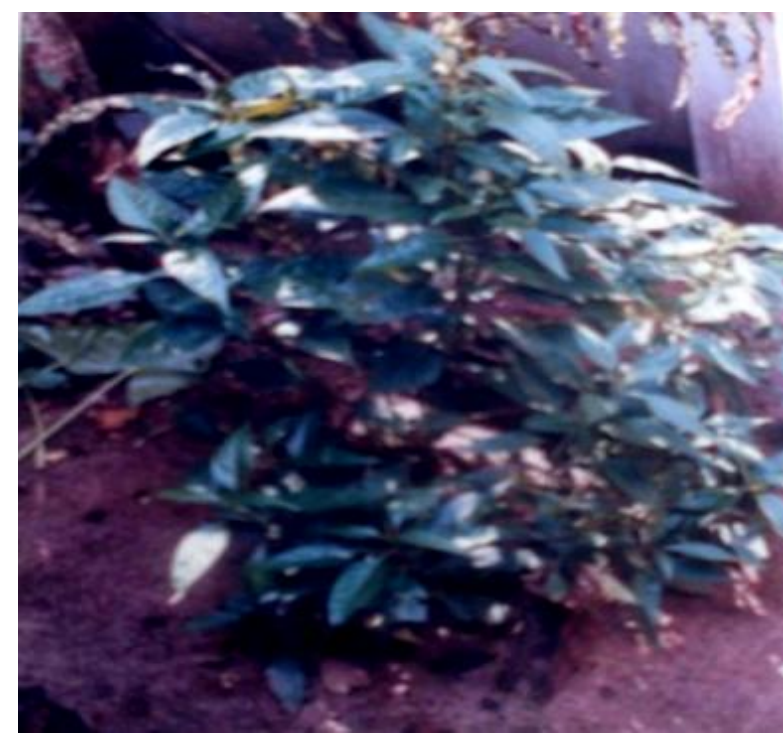

Figure 1: Adathoda vasica plant

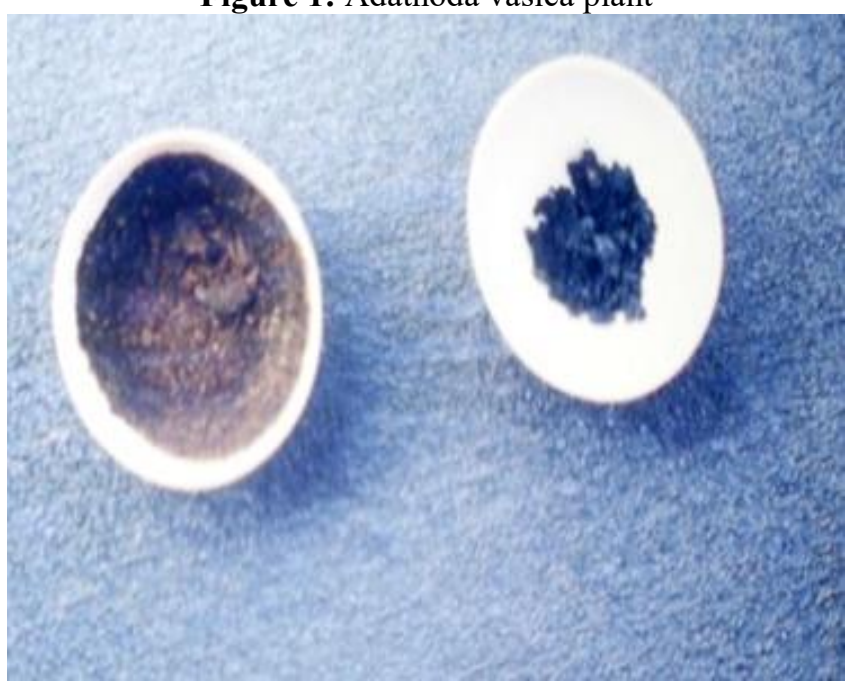

Figure 2: The crude extract of Adathoda vasica

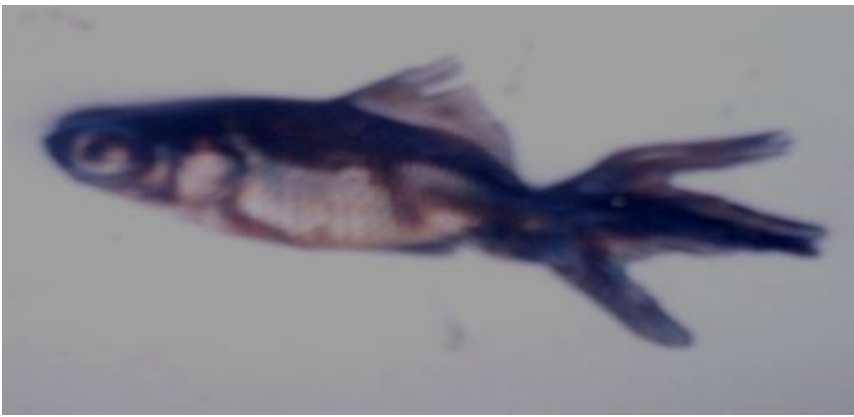

Figure 3: Carassius auratus (Black moor)

The rate of oxygen consumption showed a fluctuation from $0.0017 \pm 0.0003 \mathrm{ml} / \mathrm{hr} / \mathrm{gm} \mathrm{wt}$ at 24 hours to 0.0023 $\pm 0.0008 \mathrm{ml} / 1 / \mathrm{hr} / \mathrm{gm}$ wt at 72 hours in TD1 treatments, the control for the same being $0.0019 \pm 0.0002 \mathrm{ml} / 1 / \mathrm{hr} /$ gm wt. In TD2 treatments the rate of oxygen consumption ranged from $0.0019 \pm 0.0004 \mathrm{ml} / 1 / \mathrm{hr} / \mathrm{gm} / \mathrm{wt}$ at 24 hours to 


\section{International Journal of Science and Research (IJSR) ISSN (Online): 2319-7064 \\ Index Copernicus Value (2013): 6.14 | Impact Factor (2014): 5.611}

$0.0024 \pm 0.0006 \mathrm{ml} / 1 / \mathrm{hr} / \mathrm{gm} / \mathrm{wt}$ at 72 hours. The control values being $0.0018 \pm 0.0001 \mathrm{ml} / 1 / \mathrm{hr} / \mathrm{gm} \mathrm{wt}$.

Table 1: Oxygen consumption of Carassius auratus subsequent to TD1\&TD2 treatments

\begin{tabular}{|c|c|c|c|c|}
\hline & $\begin{array}{c}\text { Normal (mg } \\
\text { Dosage }\end{array}$ & 24hours & 48hours & 72ours \\
\hline & $0.0019 \pm$ & $0.0017 \pm$ & $0.0022 \pm$ & $0.0023 \pm$ \\
TD1 & 0.0002 & 0.0003 & 0.0006 & 0.0008 \\
\hline & $0.0018 \pm$ & $0.0019 \pm$ & $0.0024 \pm$ & $0.0024 \pm$ \\
TD2 & 0.0001 & 0.0004 & 0.0001 & 0.0006 \\
\hline
\end{tabular}

The total protein of muscle tissue in TD1 treatments ranged from $46-34 \pm 0.123 \mathrm{mg} \%$ at 24 hours to $55.23 \pm$ $0.31 \mathrm{mg} \%$ at 72 hours (control $48.11 \pm 0.012 \mathrm{mg} \%$ ). In case of liver tissue it ranged from $43.40 \pm 0.160 \mathrm{mg} \%$ at 24 hours to $50.31 \pm 1.861 \mathrm{mg} \%$ at 72 hours (control 44.34 $\pm 1.020 \mathrm{mg} \%)$. In case of head kidneys the same ranged from $35.85 \pm 0.130 \mathrm{mg} \%$ at 24 hours to $46.01 \pm$ $1.030 \mathrm{mg} \%$ at 72 hours (control $136.79 \pm 1.014 \mathrm{mg} \%$ ).

In TD2 treatments the total protein content of muscle tissue ranged from $49.10 \pm 0.184 \mathrm{mg} \%$ at 24 hours to $56.04 \pm 0.139 \mathrm{mg} \%$ at 72 hours (control $48.32 \pm 0.014$ $\mathrm{mg} \%$. The same for liver tissue varied from $45.932 \pm$ $0.016 \mathrm{mg} \%$ at 24 hours to $51.42 \pm 0.021 \mathrm{mg} \%$ at 72 hours (control $45.60 \pm 0.129 \mathrm{mg} \%$ ). In case of head kidney tissue the same ranged from $37.52 \pm 0.166 \mathrm{mg} \%$ at 24 hours to $47.62 \pm 0.120 \mathrm{mg} \%$ at 72 hours (control $37.31 \pm 0.124 \mathrm{mg} \%)$.

The glycogen content in muscle tissues subsequent to TD1 treatment ranged from $0.717 \pm 0.013 \mathrm{mg} \%$ at 24 hours to $1.893 \pm 0.014 \mathrm{mg} \%$ at 72 hours (control $0.887 \pm$ $0.011 \mathrm{mg} \%)$. The same for liver tissue ranged from $1.030 \pm 0.016 \mathrm{mg} \%$ at 24 hours to $1.920 \pm 0.006 \mathrm{mg} \%$ at 72 hours (control $1.120 \pm 0.003 \mathrm{mg} \%$ ). Whereas for head kidney tissue the same ranged from $0.392 \pm 0.010 \mathrm{mg} \%$ at 24 hours to $0.532 \pm 0.016 \mathrm{mg} \%$ at 72 hours (control $0.392 \pm 0.013)$. In TD2 treatments the glycogen content of muscle tissue ranged from $0.942 \pm 0.002 \mathrm{mg} \%$ at 24 hours to $1.432 \pm 0.132 \mathrm{mg} \%$ at 72 hours (control 0.893 $\pm 0.014 \mathrm{mg} \%$ ). The same for liver ranged from 1.468 $\pm 0.137 \mathrm{mg} \%$ at 24 hours to $1.983 \pm 0.843 \mathrm{mg} \%$ at 72 hours (control $1.401 \pm 0.042 \mathrm{mg} \%$ ). In case of head kidney tissue the same ranged from $0.499 \pm 0.032 \mathrm{mg} \%$ at 24 hours to $0.593 \pm 0.124 \mathrm{mg} \%$ at 72 hours (control 0.430 $\pm 0.011 \mathrm{mg} \%$ ).

The hematological parameters observed showed the following variations. In TD1 treatment the RBC count ranged from $184000 \pm 1600 / \mathrm{mm}^{3}$ at 24 hours to 200000 $\pm 1900 / \mathrm{mm}^{3}$ the control value being $146000 \pm 2300 /$ $\mathrm{mm}^{3 .}$. The same for TD2 treatment ranged from 162000 $\pm 2400 / \mathrm{mm}^{3}$ at 24 hours to $220,000 \pm 1890 / \mathrm{mm}^{3}$ at 72 hours the control being $146000 \pm 2300 / \mathrm{mm}^{3}$.In TD1 treatment the WBC count ranged from $5700 \pm 493 / \mathrm{mm}^{3}$ at 24 hours to $6092 \pm 301 / \mathrm{mm}^{3}$ at 72 hours the control value being $5400 \pm 203 \mathrm{~mm}^{3}$. The same for TD2 treatment ranged from $5810 \pm 311 / \mathrm{mm}^{3}$ at 24 hours to $6152 \pm 200 / \mathrm{mm}^{3}$ at 72 hours and control value for the same being $5400 \pm$ $203 / \mathrm{mm}^{3}$. In TD1 treatment the, $\mathrm{Hb}$ content ranged from $642 \pm 0.19 \mathrm{mg} \mathrm{Hb} / 100 \mathrm{ml}$ at 24 hours to $7.54 \pm$ $0.30 \mathrm{mg} \mathrm{Hb} / 100 \mathrm{ml}$ at 72 hours and the control being $6.80 \pm 0.03 \mathrm{mg} \mathrm{Hb} / 100 \mathrm{ml}$. The same for TD2 treatment ranged from $7.42 \pm 0.18 \mathrm{mg} \mathrm{Hb} / 100 \mathrm{ml}$ at 24 hours to $8.30 \pm 0.02 \mathrm{mg} \mathrm{Hb} / 100 \mathrm{ml}$ at 72 hours, the control value being $6.80 \pm 0.03 \mathrm{mg} \mathrm{Hb} / 100 \mathrm{ml}$. The candidate tested (C.auratus) has responded positively with respect to the hematological parameters studied. Though it is too early to give a comprehensive idea with regard to the plant candidate Adathoda vasica, it certainly has a positive physiological effect on the fish Carassius auratus.

Table 2: Protein content of various tissues of Carassius auratus subsequent to TD1 and TD2 treatments

\begin{tabular}{|c|c|c|c|c|c|c|c|c|}
\hline \multirow{2}{*}{ Tissues } & \multicolumn{2}{|c|}{ Normal (mg \%) } & \multicolumn{2}{c|}{ 24hours (mg \%) } & \multicolumn{2}{c|}{ 48hours (mg \%) } & \multicolumn{2}{c|}{ 72hours (mg \%) } \\
\cline { 2 - 9 } & TD1 & TD2 & TD1 & TD2 & TD1 & TD2 & TD1 & TD2 \\
\hline Muscle & $48.11 \pm 0.012 *$ & $48.32 \pm 0.014 *$ & $46.34 \pm 0.123$ & $49.10 \pm 0.184$ & $52.39 \pm 0.603$ & $53.36 \pm 0.131$ & $55.23 \pm 0.31$ & $56.04 \pm 0.139$ \\
\hline Liver & $44.34 \pm 1.020$ & $45.60 \pm 0.129$ & $43.40 \pm 0.160$ & $45.932 \pm 0.016$ & $47.79 \pm 0.891$ & $48.63 \pm 0.142$ & $50.31 \pm 1.861$ & $51.42 \pm 0.021$ \\
\hline Head kidney & $36.79 \pm 1.014$ & $37.31 \pm 0.124$ & $35.85 \pm 0.130$ & $37.52 \pm 0.166$ & $40.39 \pm 1.423$ & $41.01 \pm 0.012$ & $46.01 \pm 1.030$ & $47.62 \pm 0.20$ \\
\hline
\end{tabular}

Table 3: Glycogen content of various tissues of Carassius auratus subsequent to TD1 and TD2 treatments

\begin{tabular}{|c|c|c|c|c|c|c|c|c|}
\hline \multirow{2}{*}{ Tissues } & \multicolumn{2}{|c|}{ Normal (mg \%) } & \multicolumn{2}{c|}{ 24hours (mg \%) } & \multicolumn{2}{c|}{ 48hours (mg \% } & \multicolumn{2}{c|}{ 72hours (mg \%) } \\
\cline { 2 - 8 } & TD1 & TD2 & TD1 & TD2 & TD1 & TD2 & TD1 & TD2 \\
\hline Muscle & $0.887 \pm 0.011 *$ & $0.893 \pm 0.014 *$ & $0.717 \pm 0.013$ & $0.942 \pm 0.002$ & $0.912 \pm 0.003$ & $1.031 \pm 0.103$ & $1.893 \pm 0.014$ & $1.432 \pm 0.132$ \\
\hline Liver & $1.120 \pm 0.003$ & $1.401 \pm 0.042$ & $1.030 \pm 0.016$ & $1.468 \pm 0.137$ & $1.870 \pm 0.041$ & $1.924 \pm 0.356$ & $1.920 \pm 0.006$ & $1.983 \pm 0.843$ \\
\hline Head kidney & $0.392 \pm 0.013$ & $0.430 \pm 0.011$ & $0.392 \pm 0.010$ & $0.499 \pm 0.032$ & $0.484 \pm 0.014$ & $0.561 \pm 0.005$ & $0.532 \pm 0.016$ & $0.593 \pm 0.124$ \\
\hline
\end{tabular}

The present study was an attempt to throw some light on the effect of $A$. vasica extract on the stress- metabolism axis of the ornamental fish $C$. auratus. The fluctuations seen in the haematological parameters studied shows a positive impetus to the stress- metabolism axis indicating an adaptive stress response. Iversen et al., (1998) has studied the effect of physical stressors on certain hematological parameters.
According to Iwama et al.,(1999) elevated levels of TEC and TEC at 48 hours and 72 hours in both TD I and TD 2 treatments indicates an improvement in its growth. The slight rise in $\mathrm{Hb}$ content $(7.54+0.3 \mathrm{mg} 100 \mathrm{ml} /$ blood) probably accounts for the high metabolic activity coupled with the rate of oxygen consumption. 


\section{International Journal of Science and Research (IJSR) \\ ISSN (Online): 2319-7064 \\ Index Copernicus Value (2013): 6.14 | Impact Factor (2014): 5.611}

Table 4: Hematological parameters of Carassius auratus subsequent to TD1 and TD2 treatments

\begin{tabular}{|c|c|c|c|c|}
\hline Dosage & Normal & 24hours & 48hours & 72hours \\
\hline \multirow{3}{*}{ TD1 } & $\mathrm{A}^{*}: 146000 \pm 2300$ & $184000 \pm 1600^{*}$ & $200000 \pm 3600$ & $200000 \pm 1900$ \\
\cline { 2 - 5 } & $\mathrm{B}^{*}: 5400 \pm 203$ & $5700 \pm 493$ & $5810 \pm 199$ & $6092 \pm 301$ \\
\cline { 2 - 5 } & $\mathrm{C}^{*}: 6.80 \pm 0.03$ & $6.42 \pm 0.19$ & $7.86 \pm 0.02$ & $7.54 \pm 0.3$ \\
\hline \multirow{3}{*}{ TD2 } & $\mathrm{A}^{*}: 146000 \pm 2300$ & $162000 \pm 2400$ & $200000 \pm 2830$ & $220000 \pm 1890$ \\
\cline { 2 - 5 } & $\mathrm{B}^{*}: 5400 \pm 203$ & $5810 \pm 311$ & $5911 \pm 132$ & $6152 \pm 200$ \\
\cline { 2 - 5 } & $\mathrm{C}^{*}: 6.80 \pm 0.03$ & $7.42 \pm 0.18$ & $7.96 \pm 0.29$ & $8.30 \pm 0.02$ \\
\hline
\end{tabular}

\section{Conclusion}

Adathoda vasica methanolic extract dose have a growth promoting effect on Carassius auratus. It is very early to comment on the physiological mode of action of the plant extract, but it certainly opens up an ecofriendly avenue for further scientific investigations.

\section{References}

[1] Frederickson, C. Endresen and H.I. Wergel, Immunosuppressive effect of a low molecular weight surface protein from Reni bacterium salmoniplnarum on lymphocytes of Atlantic salmon (Salmo Salvable).Fish and Shellfish immunology.7: 273-282, 1997.

[2] C.F. Watson, K.N Baer and W.H, Benson, Dorsal gill incision: A simple method for obtaining blood samples in small fish. Environ Toxicol Chemistry 8:1-5, 1989.

[3] D.S. Murthy, General aspects of fisheries development and scenario in Andhra Pradesh. Fish chimes, 21(1):9193, 2001

[4] G.K.Iwama, M.M Vijayan and J.D.Morgan, The stress response in fish, in Ichthyology, by D.N.Saksena.pp.4757, 1999.

[5] M.Iversen, B, Finstad and K.J Nilssen, Recovery from loading and transport stress in Atlantic salmon Smolts.Aquaculture, 168: 387-394, 1998.

\section{Author Profile}

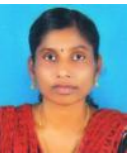

Ambili. T received the B.Sc. degree in Zoology from Sree Narayana Womens College, kollam. B.Ed in Natural Science taken in 2000. M.Sc. degree in Zoology from Fatima Mata National College,Kollam in 2003. In 2004 awarded SET and taken DCA. M. Phil in Aquatic Biology and Fisheries from the Department of Aquatic Biology \& Fisheries in the University of Kerala, Kariavattom in 2012. All the degrees were received from the University of Kerala, Thiruvananthapuram, India. She has published 7 research papers. She now is doing Ph.D in Zoology at Zoology Research Centre, Department of Zoology, Fatima Mata National College, Kollam, University of Kerala, India.

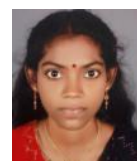

Reenamole.G.R received the B.Sc. degree in Zoology from H.H.M.S.P.B.N.S.S.College for Women, Neeramankara in 2002. B.Ed in Natural Science taken in 2003 from Govt. Anchal College, Kollam. M.Sc. degree in Zoology from Mahatma Gandhi College, Thiruvananthapuram in 2006. M. Phil in Aquatic Biology and Fisheries from the Department of Aquatic Biology \& Fisheries in the University of Kerala, Kariavattom in 2012. All the degrees were received from the University of Kerala, Thiruvananthapuram, India. She has published 7 research papers and designed a text book of "Vellayani Fish Census- a Field Guide and Report" (Author : Dr. A. Biju Kumar \& Dr. Pramod Kiran R.B) published by Dept. of Aquatic Biology and Fisheries,
University of Kerala and Supported by Agency of Development of Aquaculture, Kerala (ADAK) 2013. During 2008-2009, she worked as a Project Fellow in Central Marine Fisheries Research Institute in Vizhinjum, Thiruvananthapuram, Kerala, India. She now is doing Ph.D in Zoology at Zoology Research Centre, Department of Zoology, Fatima Mata National College, Kollam, University of Kerala, India.

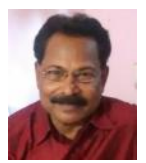

Dr. F. George D'Cruz took his B.sc, M.Sc, and Ph.D degrees from the University of Kerala, India. After Post graduation, he joined Fatima Mata National College (at present a leading Autonomous College in Kerala) under the University of Kerala as Lecturer in 1979. In 1998 he took his Ph.D in Zoology, through Part time Research, while serving as a Professor. In Zoology, his area of specialization was Fisheries and Environmental Toxicology, Biodiversity, Wetland Ecology and Fish Diversity. In 2008, he retired as the HOD of Zoology and at present holds the post of honorary director of the Zoology Research Centre, under the Department of Zoology in the same college. There are about 20 Research papers published in Research Journals and more than 50 scientific papers presented in Seminars, Symposia and other Public functions in his credit. At present he is guiding students for their Ph.D in Fish Diversity and Wetland Ecology. He has authored three books and co-authored three other books on various topics like Fisheries, Environmental Biology and Human Evolution, in addition to Scientific Articles in Popular Journals and Print media. There are 16 Radio talks through All India Radio and 15 talks through Radio Benziger, Kollam on various scientific topics under Fisheries, Biodiversity Conservation, Environmental Biology, etc. Dr. F. George D'Cruz's Contributions as Subject Expert Member in various State Government Bodies like District (Kollam) Monitoring Committee Kerala Forestry Project, Department of Forest (1996-2002), District (Kollam) Forest Extension and Information Centre, Department of Forest (1996-2002), Committee for Project Formulation and Implementation, Department of Fisheries (2002-2004), State Council of Educational Research and Training (1999-2005), Wetland Cell (2004-2006), etc., are noteworthy. He also served as the State Level Programme Coordinator of the Kerala State Biodiversity Board in Preparing People's Biodiversity Register (2009-2011). He had completed 3 projects on Research and Conservation of the State Government Agencies (Department of Fisheries, Department of Forest and Kollam Corporation). 